
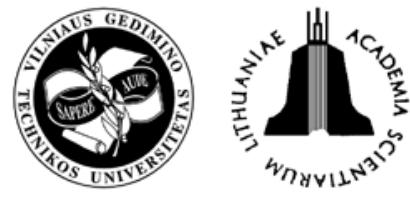

TRANSPORT

2008

23(4): 351-355

\title{
RESEARCH ON THE COMPATIBILITY OF THE CALCULATION METHODS OF ROLLING-STOCK BRAKES
}

\author{
Gintautas Bureika $^{1}$, Šarūnas Mikaliūnas ${ }^{2}$ \\ Dept of Railway Transport, Vilnius Gediminas Technical University \\ J. Basanavičiaus g. 28, 03224 Vilnius, Lithuania \\ E-mails: ${ }^{1}$ gintautas.bureika@ti.vgtu.lt; ${ }^{2}$ sarunas.mikaliunas@adm.vgtu.lt
}

Received 11 March 2008; accepted 3 October 2008

\begin{abstract}
One of the main tasks approached by the European Union is the liberalisation of railway transport service market. The foremost problem solved in this paper is the interoperability of various railway systems in the countries of the European Union. Thus, the immediate goal is to solve the problem of the interoperability of different railway systems used in the European Union. A distinction between railway track gauges (from 1435 to $1668 \mathrm{~mm}$ ), particular couples of wagons, various clearances of rolling stock, different systems of infrastructure etc. are the main impediments. One of the problems in the nearest future will be the evaluation of the brakes of different wagons produced in Western Europe and the former Soviet Union. Freight trains in Lithuania consist of these two types of wagons, and therefore some problems of correcting the results of calculating braking distances and brake force may arise. The main object of this research is to investigate the methods evaluating the brakes of rolling-stock and to assess the possibilities of integrating and harmonizing these different methods. The reliability of the methods evaluating the brakes of rolling-stock is one of the most important components enabling the interoperability of railway transport in the EU network. The brakes of Russian wagons are calculated by MPS Rules for Traction Calculations, approved by the Russian Ministry of Transport (till 2004 - Ministry of Communication Ways of Russia)). On the other hand, the brakes of the wagons produced in Western Europe should be calculated applying TSI (Technical Specifications for Interoperability) methodology. The main parameter following TSI (Technical Specifications for Interoperability) methodology is braked mass and following MPS (Railway Transport Ministry of Russia) method - a pressing force of the brake shoes. The questions of determining the braked mass of wagons and correcting mean braking distance are presented. The compatibility of two different evaluating methods is discussed. Finally, the basic conclusions are given.
\end{abstract}

Keywords: railway interoperability, passengers and freight wagons, braking distance, braked mass, methods of calculating brakes, improvements to calculation correctness.

\section{Introduction}

One of the main tasks approached by the European Union is the liberalisation of railway transport service market. Thus, the immediate goal is to solve the problem of the interoperability of different railway systems used in the European Union. These wide-ranging problems are analyzed by Bessenyei (2008); Butkevičius (2007). The problems of rolling stock technical stability are investigated by Kisilowski et al. (Kisilowski and Zalewski 2008). The factors of the deterioration of railway vehicles are estimated by Lingaitis and Vaičiūnas (2008) and the particularities of railway switches wearing are explored by Gailiene et al. (2008). A distinction between railway track gauges (from 1435 to $1668 \mathrm{~mm}$ ), particular couples of wagons, various clearances of rolling stock and different systems of infrastructure are the main impediments. According to the Eu- ropean Union Council Directive 2001/16/EU, all member states should attempt to eliminate these disadvantages in their railways. One of the problems in the nearest future will be the evaluation of the brakes of different wagons produced in Western Europe and the former Soviet Union. Freight trains could consist of two types of wagons, and thus some problems of correcting the results of calculating braking distances and brake force may arise. The brakes of Russian wagons are calculated by MPS (Russian version МПС - Министерство путей сообщения) Rules for Traction Calculations, approved by the Russian Ministry of Transport (till 2004 - Ministry of Communication Ways of Russia). The principal research on rolling stock traction in Russia has been made by Grebenyuk (Гребенюк 2003), Grebenyuk et. al. (Гребенюк и др. 1987) and Krylov et al. (Крылов и др. 1991). A number of 
scientists including Bureika and Subačius (2002); Bureika et al. (2004); Vaičiūnas et al. (2004); Liudvinavičius and Lingaitis (2007) are investigating this issue in Lithuania. On the other hand, the brakes of the wagons produced in Western Europe should be calculated following TSI (Technical Specifications for Interoperability) methodology referring to the resolution approved by the EU Commission on 28 July 2006 (2006/861/EC). The reliability of the methods evaluating the brakes of rolling-stock is one of the most important components enabling the interoperability of railway transport in the EU network. Under TSI methodology, braked mass is the main parameter, whereas MPS method points to a pressing force of the brake shoes.

The main object of this research is to investigate the methods evaluating the brakes of rolling-stock and to assess the possibilities of integrating and harmonizing these different methods.

\section{Determining Vehicle Braking Force Fitted with UIC Air Brake for Passenger Trains}

According to the resolution issued by the EU Commission on 28 July 2006 (2006/861/EC), the braked mass $B_{b r}$ of a wagon shall be established under calculation procedures considering the following conditions: maximum speed $\leq 120 \mathrm{~km} / \mathrm{h}$; the wheels are braked on both sides and have a nominal diameter from 920 to $1000 \mathrm{~mm}$; the brake shoes are made of P10 cast iron; the blocks are type $B_{g}$ (single) or $B_{g u}$ (tandem); force applied by the shoes 5 to $40 \mathrm{kN}$ with $B_{g}$ and 5 to $55 \mathrm{kN}$ with $B_{g u}$ blocks.

The braked mass $B_{b r}$ shall be calculated using the following formula:

$$
B_{b r}=\frac{k \cdot \sum F_{d y n}}{g}
$$

where: $k$ - a dimensionless factor that depends on the type of a shoe $\left(B_{g}\right.$ or $\left.B_{g u}\right)$ and on the contact force of each shoe; $\sum F_{d y n}$ - the sum of all forces applied by the shoes whilst the vehicle is moving. mula:

$\sum F_{d y n}$ shall be calculated using the following for-

$$
\sum F_{d y n}=\left(F_{t} \cdot i-i^{\star} \cdot F_{R}\right) \cdot \eta_{d y n}
$$

where: $F_{t}-e$ ffective force at the brake cylinder, once the recoil of the cylinders and rigging has been deducted, $\mathrm{kN} ; i$ - total increment for brake rigging; $i^{\star}-$ the increment after central rigging (normally 4 for two-axled wagons and 8 for bogie wagons); $\eta_{d y n}$ - mean efficiency of rigging whilst the vehicle is moving, mean between two maintenance visits (can be up to 0.91 , depending on the type of rigging); $F_{r}$ - opposing force applied from the regulator (usually $2 \mathrm{kN}$ ).

The $k$ curves used to calculate the braked mass are given by mathematical formulae of the following type:

$$
k=a_{0}+a_{1} \cdot F_{d y n}+a_{2} \cdot F_{d y n}^{2}+a_{3} \cdot F_{d y n}^{3} .
$$

The values of coefficients $a_{i}$ are given in Table 1 .

The determination of the braked mass percentage to calculate braking distance using assessment graphics in Fig. 1 refer to EU Commission decision made on 28 July 2006.

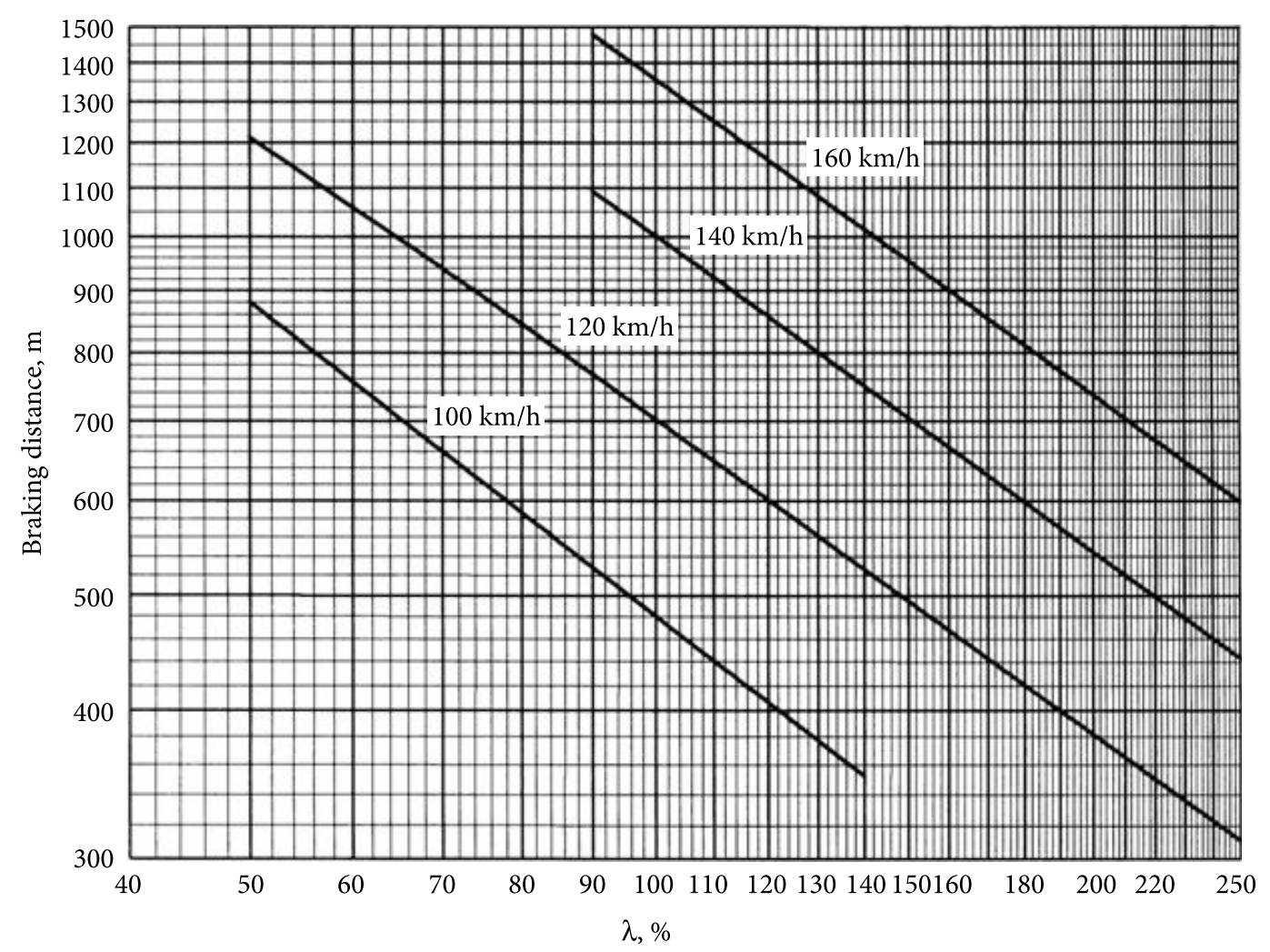

Fig. 1. Assessment graphics of the braked mass percentage $\lambda$ of passenger wagons 
Table 1. Values of coefficients in formula (3)

\begin{tabular}{ccccc}
\hline Coefficient & $a_{0}$ & $a_{1}$ & $a_{2}$ & $a_{3}$ \\
\hline$k_{B g}$ & 2.145 & $-5.38 \cdot 10^{-2}$ & $7.8 \cdot 10^{-4}$ & $-5.36 \cdot 10^{-6}$ \\
$k_{B g u}$ & 2.137 & $-5.14 \cdot 10^{-2}$ & $8.32 \cdot 10^{-4}$ & $-6.04 \cdot 10^{-6}$ \\
\hline
\end{tabular}
taken:

The results of minimum braked mass $B_{b r}$ shall be

$$
S=\frac{C}{\lambda+D}
$$

and

$$
\lambda=\frac{C}{S}-D
$$

Calculation results are given in Table 2.

Table 2. Calculation of braked mass percentage $\lambda$

\begin{tabular}{ccc}
\hline$v, \mathrm{~km} / \mathrm{h}$ & $C$ & $D$ \\
\hline 100 & 52840 & 10 \\
120 & 83634 & 19 \\
140 & 119179 & 19 \\
160 & 161280 & 19 \\
\hline
\end{tabular}

NOTE. Formulae (4) and (5) are valid inside the limits corresponding to the extremities of the lines in Fig. 1.

\section{Determining Wagon Braking Force Fitted with a UIC Air Brake for Freight Trains}

\subsection{Number of Tests}

At least 4 valid tests shall be carried out to calculate the mean. All braking distances obtained shall be corrected.

The mean shall be accepted if meeting the following simultaneously checked criteria:

- Criterion 1

$$
\frac{\text { Standard deviation of sample }\left(\sigma_{n}\right)}{\text { Mean of sample }(\bar{S})} \leq 3.0 \% \text {; }
$$

\section{- Criterion 2:}

|Extreme value $\left(S_{e}\right)-$ mean $(\bar{S}) \mid \leq 1.95 \cdot \sigma_{n}$,

where: $S_{e}$ - braking distance furthest from the mean.

NOTE. If one of the two criteria is not met, then a supplementary test shall be carried out (rejecting the extreme value $S_{e}$ if criterion 2 is not met and $n \geq 5$ ).

With the new values thus obtained, criteria 1 and 2 shall then be checked where: $S_{i}$ - braking distance measured in test ' $i$, after correction, $\mathrm{m} ; S$ - mean braking distance, $\mathrm{m} ; n$ - the number of tests; $\sigma_{n}$ - the standard deviation of the sample $\sigma$ and it is equal:

$$
\sigma_{n}=\sqrt{\frac{\sum\left|S_{i}-\bar{S}\right|^{2}}{n}}
$$

\subsection{Method of Evaluating the Results of Testing Brakes}

Braking distance obtained in test ' $j$ ' shall be corrected to take into account the following factors: nominal speed in relation to the initial speed measured in the test and a gradient of the test track.

Applying the following formula shall make the correction:

$$
\frac{v_{\text {jnom }}^{2}}{2 \cdot 3.6^{2} \cdot S_{\text {jcorr }}}=\frac{v_{\text {jmeas }}^{2}}{2 \cdot 3.6^{2} \cdot S_{\text {jmeas }}}-\frac{g}{\rho} \cdot \frac{i}{1000} .
$$

Transformation gives the following:

$$
S_{j c o r r}=\frac{3.933 \cdot \rho \cdot v_{j n o m}^{2}}{3.933 \cdot \rho \cdot v_{j n o m}^{2}-i \cdot S_{j m e a s}} \cdot S_{j m e a s},
$$

where: $S_{\text {jcorr }}$-corrected braking distance (corresponding to the nominal speed in test $j$ ), $\mathrm{m} ; S_{\text {jmeas }}$ - braking distance measured in test $j, \mathrm{~m} ; v_{\text {jnom }}$ - nominal initial speed in test $j, \mathrm{~km} / \mathrm{h} ; v_{\text {jmeas }}$ - initial speed measured in test $j, \mathrm{~km} / \mathrm{h} ; i-$ mean gradient over $S_{\text {jmeas }}$ on the test track which is positive (+) for an upgrade and negative (-) for a downgrade, $\mathrm{mm} / \mathrm{m} \% ; \rho$ - the coefficient of the inertia of 'rotating masses' defined as follows:

$$
\rho=1+\frac{m_{r}}{m},
$$

where: $m$ - the mass of a tested train or vehicle, $m_{r}$ - the equivalent mass of rotating components (wheel-sets, shafts, etc.).

NOTE. In case no exact value is known $\rho=1.15$ for locomotives and $\rho=1.04$ for wagons shall be used.

\section{Correcting Mean Braking Distance}

Mean braking distance $\bar{S}$ shall be corrected taking into account the following factors:

a) The dynamic efficiency of brake rigging tested as compared with mean in-service value and, for disc brakes, mean wheel diameter on the vehicles tested as compared to the diameter of the half-worn wheel. For wagons with P10 block brakes and conventional brake rigging dynamic efficiency shall be corrected.

b) Mean braking distance shall be corrected using the following formulae:

$$
F_{\text {corr }}=F_{\text {tset }} \cdot \frac{\eta_{m}}{\eta_{\text {test }}} \cdot \frac{d_{\text {test }}}{d_{m}}
$$

and

$\bar{S}_{\text {corr }}=t_{e} \cdot v_{\text {nom }}+\frac{F_{\text {test }}+W_{m}}{F_{\text {corr }}+W_{m}} \cdot\left(\bar{S}-v_{\text {nom }} \cdot t_{e}\right)$,

where: $\bar{S}_{\text {corr }}$-corrected mean braking distance, $\mathrm{m} ; \bar{S}$ - mean braking distance in the test, $\mathrm{m}$; 
$t_{e}$ - equivalent build-up time for braking force, $s$;

$v_{\text {nom }}$ - nominal initial speed in the test, $\mathrm{m} / \mathrm{s} ; d_{\text {test }}-$ mean wheel diameter on the vehicles tested, $\mathrm{mm}$; $d_{m}$ - the diameter of the half-worn wheel, mm; $F_{\text {corr }}$ - corrected braking force, $\mathrm{kN} ; F_{\text {test }}$ - mean braking force in the test, $\mathrm{kN} ; \eta_{m}$ - the efficiency of brake rigging in average service conditions; $\eta_{\text {test }}$ - the efficiency of brake rigging in the test; $W_{m}$ - mean resistance to forward motion.

c) Real filling time in relation to nominal is $4 \mathrm{~s}$. This correction shall only be applied to tests with an isolated vehicle.

The following correction formula shall be applied:

$\bar{S}_{\text {corr }}=\left(2-\frac{t_{s}}{2}\right) \cdot v_{\text {nom }}+\bar{S}$,

where: $\bar{S}_{\text {corr }}$ - corrected mean braking distance, $\mathrm{m} ; \bar{S}-$ mean braking distance, $\mathrm{m} ; t_{s}-$ measured mean filling time for the brake cylinders, s; $v_{\text {nom }}$ - nominal initial speed in the tests, $\mathrm{m} / \mathrm{s}$.

\section{Compatibility of TSI and MPS Methods}

The braked mass $B_{b r}$ of Russian freight wagons shall be calculated:

$$
B_{b r}=\frac{10}{7} \cdot \sum K \cdot \gamma
$$

where: $K$ - a total pressing force of the brake shoes, tf; $\gamma$ - the empirical coefficient determined as a function of brake cylinder filling time, initial pressure rising level and a total pressing force of the shoes (see Fig. 2).

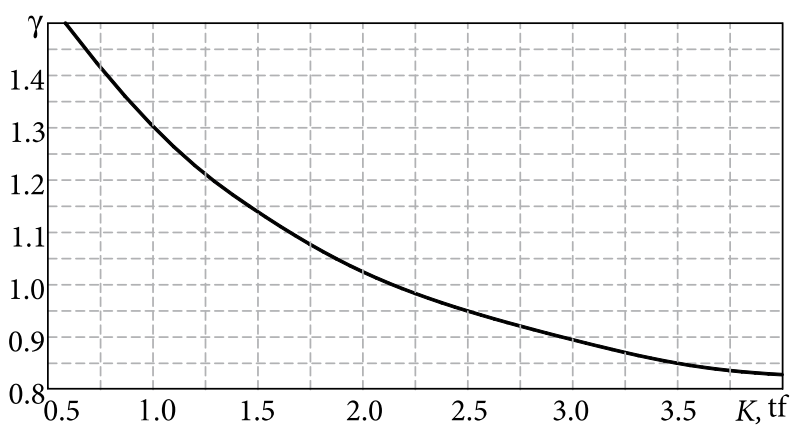

Fig. 2. Nomogram of empirical coefficient $\gamma$

Braking coefficient $\vartheta_{b r}$ (by MPS) is calculated by formula:

$$
\vartheta_{b r}=\frac{\sum K}{m_{w}},
$$

where: $\sum K-$ a total pressing force of the brake pads of the wagon, tf; $m_{w}$ - the gross mass of the wagon, t.

The values of the gross masses of Russian freight wagons, the pressing forces of the brake pads $K$ and the number of the brake pads of the wagon are taken from a technical manual of Grebenyuk et al. [Гребенюк, Долганов, Скворцова 1987]. If $\sum K$ and $\gamma$ are known, it is possible to calculate the braked mass of freight wagons. If the braked mass $B_{b r}$ is known, there is an opportunity to choose the required pressure force of the brake shoes $K$ for designing new wagons.

According to formula (13), it is possible to calculate the braked masses $B_{b r}$ of all types of Russian freight wagons. The calculation results and errors of the braking mass of freight wagons are presented in Table 3 .

The TSI methodology affords to evaluate the braking distances of Russian rolling-stock by linear equations. It is supposed that when applying both methods,

\begin{tabular}{|c|c|c|c|c|c|c|c|c|}
\hline $\begin{array}{l}\text { State of } \\
\text { wagon } \\
\text { loading }\end{array}$ & $\begin{array}{c}\text { Gross mass } \\
\text { of wagons } \\
m_{w}, \mathrm{t}\end{array}$ & $\begin{array}{l}\text { Pad's pressing } \\
\text { force } K, \mathrm{kN} \\
(\mathrm{tf})\end{array}$ & $\begin{array}{l}\text { Total pads' } \\
\text { pressing force } \\
\Sigma K, \mathrm{kN}(\mathrm{tf})\end{array}$ & $\begin{array}{c}\text { Braking } \\
\text { coefficient } \\
\vartheta_{b r} \text { by MPS }\end{array}$ & $\begin{array}{l}\text { Conversion } \\
\text { coefficient } \gamma\end{array}$ & $\begin{array}{c}\text { Calculated } \\
\text { braking mass } \\
B_{b r}, \mathrm{t}\end{array}$ & $\begin{array}{c}\text { Braking mass } \\
B_{b r} \text { received } \\
\text { by MPS, } \mathrm{t}\end{array}$ & $\begin{array}{c}\text { Bias of } \\
\text { braking mass } \\
\text { determination, \% }\end{array}$ \\
\hline \multicolumn{9}{|c|}{ four axles wagons with 8 brake pads } \\
\hline loaded & 84 & $37.3(3.8)$ & $298.2(30.4)$ & 0.36 & 0.83 & 36.0 & 36 & 0 \\
\hline $\begin{array}{l}\text { semi- } \\
\text { loaded }\end{array}$ & 42 & $22.6(2.3)$ & $180.5(18.4)$ & 0.43 & 0.97 & 25.5 & - & - \\
\hline empty & 24 & $1.3(1.3)$ & $99.1(10.1)$ & 0.42 & 1.21 & 17.6 & 18 & 2.2 \\
\hline \multicolumn{9}{|c|}{ six axles wagons with 16 brake pads } \\
\hline loaded & 126 & $25.5(2.6)$ & $408.1(41.6)$ & 0.33 & 0.94 & 55.9 & 54 & 3.6 \\
\hline $\begin{array}{l}\text { semi- } \\
\text { loaded }\end{array}$ & 63 & $15.7(1.6)$ & $251.1(25.6)$ & 0.41 & 1.13 & 41.3 & - & - \\
\hline empty & 36 & $8.8(0.9)$ & $141.3(14.4)$ & 0.40 & 1.34 & 27.6 & 27 & 2.2 \\
\hline \multicolumn{9}{|c|}{ eight axles wagons with 16 brake pads } \\
\hline loaded & 168 & $34.3(3.5)$ & $549.4(56.0)$ & 0.33 & 0.85 & 68.0 & 72 & 5.5 \\
\hline $\begin{array}{l}\text { semi- } \\
\text { loaded }\end{array}$ & 84 & $21.4(2.18)$ & $342.4(34.9)$ & 0.42 & 0.98 & 48.8 & - & - \\
\hline empty & 48 & $12.2(1.24)$ & $194.2(19.8)$ & 0.41 & 1.22 & 34.6 & 36 & 3.8 \\
\hline
\end{tabular}

Table 3. Braking parameters of Russian freight wagons with cast-iron brakes pads

NOTE. Braking mass received by MPS is $88 \mathrm{kN}$ (9 tf) per wagon's axle. 
the rank of the definition errors of the braking distance of rolling-stock is the same as the errors of the calculated braked mass $B_{b r}$.

\section{Conclusions}

1. The braking distance of rolling stock shall be corrected taking into account two factors: nominal speed in relation to the speed measured in the test and the gradient $i$ of the tested track.

2. The differences (errors) between the values of the braked mass of Russian freight wagons estimated by TSI (Europe Union) method and calculated by MPS (Russian) method for 4 axle freight wagons with cast-iron brake shoes are (0-2.2)\%, for 6 axle freight wagons with the brake shoes $-(2-4) \%$ and for 8 axle freight wagons - up to $5.5 \%$ (Table 3 ).

3. The values of braking coefficient $\vartheta_{b r}$ for Russian freight wagons vary from 0.33 to 0.43 (Table 3 ).

4. In the nearest future, it is necessary to compile the tables for calculating the braked mass of Russian wagons exploited within EU railways.

5. The pressing force of the brake shoes $K$ and coefficient $\gamma$ (Fig. 2) are the initial data to correctly compile the conversion tables of the braked mass of Russian freight wagons.

\section{References}

Bessenyei, G. 2008. Theoretical Principles for Quantitative Evaluation of Railway Interoperability: Doctoral Dissertation. Budapest University of Technology and Economics. 91 p.

Bureika, G.; Lingaitis, L. P.; Mikaliūnas, Š. 2004. Investigation of dynamic models of independently rotating wheels of wagons, Transport 19(1): 28-31.

Bureika, G.; Subačius, R. 2002. Mathematical model of dynamic interaction between wheel-set and rail track, Transport 17(2): 46-51.

Butkevičius, J. 2007. Development of passenger transportation by railroad from Lithuania to European States, Transport 22(2): 73-79.

Gailiene, I.; Podagèlis, I.; Slepakovas, O. 2008. Research on the lifetime of the switch and assumptions of increasing it, Transport 2(23): 150-155.

Kisilowski, J.; Zalewski, J. 2008. On a certain possibility of practical application of stochastic technical stability, Eksploatacja i niezawodność - Maintenance and Reliability 1(37): 4-6.

Lingaitis, L. P.; Vaičiūnas, G. 2008. A change of complex economic indicators of passenger rolling stock deterioration, Eksploatacja i niezawodność - Maintenance and Reliability 1(37): 64-66.

Liudvinavičius, L.; Lingaitis, L. P. 2007. Electrodynamic braking in high-speed rail transport, Transport 22(3): 178-186.

Vaičiūnas, G.; Lingaitis, L. P.; Bureika, G., 2004. The determination of a complex criterion for assessing the performance of traction rolling-stocks, Transport 19(2): 63-68.

Гребенюк, П. Т.; Долганов, А. Н.; Скворцова, А. И. 1987. Тяговые расчеть: Справочник [Grebenyuk, P. T.; Dolganov, A. N.; Skvortsova, A. I. A manual for calculating rolling stock traction]. Москва: Транспорт. $272 \mathrm{c.}$

Гребенюк, П. Т. 2003. Продольная динамика поезда [Grebenyuk, P. T. Longitudinal train dynamics]. Москва: Интекст. 96 с.
Крылов, В. В.; Погребинский, М. Г.; Терещенко, В. П.; Максимов, Б. Г.; Кружалов, В. К. 1991. Особенности эксплуатации тормозов грузовых порожних поездов длиной до 504 осей [Krylov, V. V.; Pogrebinskij, M. G.; Tereschenko, V. P.; Maksimov, B. G.; Kruzhalov, V. K. The specificities of maintaining freight trains built with brakes up to the length of 504 wheel-sets], in Сборник научных трудов ВНИИЖТ [Scientific Proceedings of VNIIZT], 23-25. 